\title{
TINJAUAN FIKIH MUAMALAH TERHADAP PENERAPAN KHIYAR DALAM TRANSAKSI E-COMMERCE
}

\author{
Jamilah dan Firmansyah ${ }^{1,3}$ \\ ${ }^{1,2}$ Afiliasi: Sekolah Tinggi Ekonomi Islam SEBI. \\ Email: jamilahsalsabila@gmail.com, firms134@gmail.com
}

\begin{abstract}
ABSTRAK. Transaksi e-commerce merupakan jual beli yang alat utamanya menggunakan elektronik. Jual beli online sama halnya dengan jual beli tradisional, ada etika dan norma yang harus diterapkan agar tercipta kepuasan dan kerelaan, yaitu dengan cara memberikan hak khiyar. Penelitian ini menggunakan metode study pustaka (Library Research) yaitu menggunakan teori-teori melalui literatur-literatur buku, jurnal yang berkaitan dengan khiyar dalam transaksi e-commerce. Hasil penelitian ini dapat disimpulkan bahwa, praktek khiyar dalam transaksi e-commerce telah diterapkan melalui kebijakan bolehnya pengembalian barang akan tetapi, tidak semua khiyar dapat diterapkan dalam transaksi e-commerce hanya ada tiga khiyar yang dapat diterapkan yaitu; khiyar syarat, khiyar aib dan khiyar ru'yah.
\end{abstract}

Kata Kunci : Jual Beli, Khiyar, E-Commerce

\begin{abstract}
ABSTRACK. The e-commerce transaction is a buying and selling instrument that uses electronic equipment primarily. Online buying and selling as well as traditional buying and selling ethics and norms that must be applied in order to create satisfaction and willingness that is by giving the right khiyar. This study uses library research method which uses theories about khiyar in e-commerce transactions through book literature, journals, related to khiyar in e-commerce transactions. The results of this study can be concluded that the practice of khiyar in e-commerce transactions has been implemented through the policy of the return of goods but not all khiyar can be applied in ecommerce transactions there are only three khiyar that can be applied that khiyar syarat, khiyar aib and khiyar ru'yah.
\end{abstract}

Keyword: Buy and Sale, Khiyar, E-Commerce

\section{PENDAHULUAN}

Seiring perkembangan zaman tekhnologi berkembang semakin pesat, sehingga membuat aktifitas semakin mudah dan instan, salah satu dampak perkembangan tekhnologi juga terjadi dalam jual beli yaitu, jual beli online atau e-commerce. E-commerce adalah pembelian, pembayaran, pemasaran barang dan jasa melalui sistem elektronik, seperti internet dan jaringan komputer lainnya (Suzanto, 2015, pp. 3-5).

Transaksi e-commerce merupakan peluang besar bagi para pembisnis karena mampu memperkenalkan produk dan jasa kepada konsumen diseluruh dunia. E-commerce setidaknya memberikan enam dampak positif bagi operasi bisnis suatu perusahaan yaitu; Pertama, meningkatkan efisiensi baik secara 
materil (biaya) maupun non materil (tenaga dan waktu). Kedua, dapat menekan biaya pemasaran dan distribusi sehingga pelaku usaha hanya memerlukan modal yang relatif sedikit dalam menjalankan bisnisnya. Ketiga, memperbaiki kontrol terhadap barang. Keempat, memperbaiki rantai distribusi. Kelima, membantu perusahaan untuk menjaga hubungan yang lebih baik terhadap konsumen dan pemasok. Keenam, bagi pembeli dapat memudahkan dalam memilih beragam barang yang diinginkan serta menghemat waktu (Ardianto, 2014, p. 2).

Jual beli dalam Islam bukan hanya mengejar keuntungan dunia akan tetapi, juga keuntungan akhirat. Dasar yang paling kuat adalah firman Allah SWT:

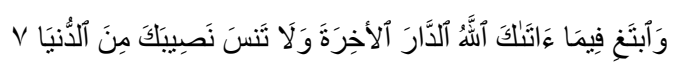

Artinya: "Carilah dengan karunia Rabbmu dengan kebahagiaanmu di akhirat akan tetapi jangan lupakan nasibmu di dunia (Q.S.Al-Qasas[28]:77)

Berdasarkan ayat di atas, Allah mengajarkan kepada pelaku bisnis baik online ataupun ofline dalam perilakunya akan selalu bersandar pada tujuan utamanya yaitu, keseimbangan (equilibrium) untuk mencapai kebahagiaan dunia dan akhirat, keseimbangan akan didapatkan dengan cara menerapkan beberapa etika dan norma dalam berbisnis yaitu bebas dari ghurur (penipuan), bebas dari maisyir (perjudian) atau spekulasi, bebas dari risywah (suap), bebas dari kemudharotan dan kemaksiatan (Aedy, 2011, pp. 97-104).

Salah satu bentuk kemaksiatan adalah kedzaliman, agar tidak terjadi kedzaliman Islam menerapkan nilai yang mendasar dalam jual beli yaitu, kejujuran dan ketulusan, ketulusan berarti kerelaan antara kedua belah pihak. Ketulusan akan didapatkan apabila penjual memberi kelonggaran kepada pembeli untuk memilih antara melanjutkan atau membatalkan transaksi, dalam istilah fikih disebut hak khiyar. Khiyar adalah mencari kebaikan dari dua perkara antara menerima atau membatalkan transaksi (Sabiq, 2006, p. 158). Khiyar disyariatkan untuk menjaga kemaslahatan, kerelaan, melindungi mereka dari kemungkinan bahaya yang merugikan perniagaan dimasa yang akan datang, memelihara kerukunan, hubungan baik serta menjalin kasih diantara sesama manusia (Markom, 2016, p. 4).

Hak-hak konsumen dapat terpenuhi dengan adanya khiyar, karena konsumen bebas melanjutkan atau membatalkan transaksi akan tetapi, permasalahannya saat ini tidak semua situs transaksi $e$-commerce menerapkan khiyar, adapun yang telah menerapkan khiyar hanya ada pada beberapa situs transaksi e-commerce. Menurut penelitian yang dilakukan oleh Muhammad Majdi Amiruddin mengatakan, ada baberapa khiyar yang telah diterapkan pada salah satu situs penjual online diantaranya; Lazada, Zalara dan blibli, ketiganya menerapkan khiyar aib dan untuk khiyar ru'yah hanya diterapakan di lazada (Amiruddin, 2016, p. 15). Berdasarkan pemaparan tersebut maka penulis tertarik untuk melakukan penelitian lebih lanjut tentang khiyar dalam transaksi e-commerce dan bagaimana pandangan syariah terhadap penerapan khiyar tersebut. 
Jurnal Ekonomi dan Perbankan Syariah

Vol. 6. No.1, April 2018: 49-62, ISSN (cet): 2355-1755 | ISSN (online): 25796437

\section{LANDASAN TEORI}

\subsection{Konsep Jual Beli}

Jual beli berasal dari kata al-bai' bentuk jama' dari kata $A l-B u y u$ ' yang artinya menjual. Menurut bahasa jual beli adalah tukar menukar harta dengan harta (As-Shawi, 2004, p. 89). Menurut pendapat yang lain jual beli adalah pertukaran yang memberikan sesuatu sebagai kompensasi atas sesuatu yang lain (Qardhawi, 1997, p. 151). Sedangkan secara terminologi terdapat beberapa pendapat yaitu (Az-Zuhaili, 2011, p. 25);

a. Menurut ulama Hanafi, jual beli adalah tukar menukar barang dengan barang, harta dengan harta yang dilakukan dengan cara tertentu, atau tukar menukar barang yang bernilai dengan cara yang sah dan khusus yakni ijab qabul atau mu'atthaa' (tanpa ijab qabul)

b. Menurut imam Nawawi, jual beli adalah tukar menukar barang dengan barang dengan maksud memberi kepemilikan.

c. Menurut Ibnu Qudamah, jual beli adalah tukar menukar barang dengan barang yang bertujuan memberi kepemilikan dan menerima hak milik.

d. Menurut Sayyid Sabiq, jual beli adalah pertukaran harta dengan harta yang menyebabkan pindahnya hak kepemilikan, serta dilandasi kerelaan dari kedua belah pihak (Sabiq, 2006, pp. 120-121)

Dalil yang menjelaskan tentang kebolehan jual beli, diantaranya sebagai berikut:

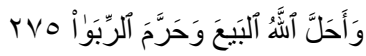

Artinya: “Allah menghalalkan jual beli dan mengharamkan riba”(Q.S. AlBaqarah [2]: 275)

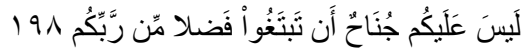

Artinya: "Tidak ada dosa bagimu untuk mencari karunia(rizki hasil perniagaan) dari Tuhanmu”. (Q.S. Al-Baqarah [2]: 198)

Adapun dalil As-sunnah yaitu Artinya: Dari Rifa'i Ibnu Khudaij ia berkata; Rosulullah SAW pernah ditanya oleh seseorang; Apakah profesi yang paling baik? Rosulullah menjawab "Seseorang yang bekerja dengan usahanya sendiri dan jual beli yang baik (dibenarkan oleh syariat Islam”. (HR. Ahmad)

\subsection{Konsep Khiyar}

Secara etimologi (bahasa) khiyar berasal dari akar kata arab yaitu, khara- yakhiru-khairan wa khiyaratan yang berarti pilihan, artinya mencari kebaikan dari dua perkara antara menerima atau membatalkan sebuah akad, lebih spesifik Mohd Murshidi menyebut khiyar sebagai hak tertentu bagi kedua belah pihak untuk meneruskan atau membatalkan kontrak jual beli (Munif A. g., 2016, p. 5). Secara terminologi ulama fikih mendefinisikan 
50 | Jamilah \& Firmansyah: Tinjauan Fikih Muamalah Terhadap Penerapan Khiyar Dalam Transaksi E-Commerce

khiyar adalah hak pilih salah satu atau kedua belah pihak untuk melangsungkan atau membatalkan transaksi yang disepakati, sesuai kondisi masing-masing pihak yang melakukan transaksi (Az-Zuhaili, 2011, p. 181).

Khiyar hukumnya boleh berdasarkan sunnah Rosulullah, Dari Abdullah bin Al-Harits ia berkata; Saya mendengar Hakim bin Hizam r.a dari Rosulullah SAW bersabda;

Artinya: "Penjual dan pembeli boleh melakukan khiyar selama mereka berdua belum berpisah. Apabila mereka benar dan jelas, maka mereka berdua diberi keberkahan didalam jual beli mereka, dan apabila mereka berdua berbohong dan merahasiakan, maka dihapuslah keberkahan jual beli mereka berdua". (HR. Bukhori)

Secara umum ulama telah membagi khiyār kepada beberapa jenis yaitu, madzhab Hanafi membagi kepada tujuh belas jenis, madzhab Syafi'i enam belas, madzhab Hambali delapan jenis dan madzhab Maliki dua jenis (AzZuhaili, 2011, pp. 181-183). Namun dalam tulisan ini penulis hanya akan menjelaskan empat khiyār utama yaitu:

1. khiyar majlis, yaitu hak khiyar yang diberikan kepada pelaku transaksi untuk membatalkan atau melanjutkan akad selama masih ditempat akad.

2. khiyar syarat, yaitu suatu khiyar dimana seorang membeli suatu dari pihak lain dengan ketentuan dia boleh melakukan khiyar pada masa atau waktu tertentu.

3. khiyar aib, adalah hak untuk melanjutkan atau membatalkan akad ketika barang yang dibeli terdapat cacat atau rusak.

4. khiyar ru'yah, adalah hak membuat pelihan yang diberikan kepada pembeli antara meneruskan atau membatalkan akad apabila telah melihat barangnya, yang tidak dilihat semasa melakukan akad (Harun, 2016, p. 4)

\section{3 Konsep E-commerce}

E-commerce adala pembelian dan penjualan barang, jasa, dan transfer dana, melalui komunikasi digital, yang mencakup semua fungsi antara perusahaan dan intra perusahaan (seperti pemasaran, keuangan, manufaktur, penjualan dan negosiasi) (El-Islamy, 2002, p. 4).

Secara umum transaksi e-commerce dapat dikategorikan dalam beberapa jenis yaitu,

1. Business to Business (B2B). Merupakan transaksi antara pelaku bisnis dengan pelaku bisnis lainnya atau merchant dengan merchant lainnya. Contoh; bizzi dan ralali. (Martadiredja, 2008, p. 93)

2. Business to consumer (B2C). Merupakan transaksi ritel dengan pembelian individual, selain itu juga dapat diartikan toko online yaitu transaksi antara merchant dengan customer. Contoh; bhinneka, berrybenka, amazon, lazada dan blibli (Pradana, 2015, pp. 5-6)

3. Consumer to Consumer (C2C). Merupakan transaksi dimana konsumen menjual produk secara langsung kepada konsumen lainnya, selain itu juga 
Jurnal Ekonomi dan Perbankan Syariah

Vol. 6. No.1, April 2018: 49-62, ISSN (cet): 2355-1755 | ISSN (online): 2579-

6437

| 51

merupakan individu yang mengiklankan produk barang atau jasa, pengetahuan, maupun keahlian di salah satu situs lelang. Contoh; elevenia, puali, tokopedia, bukalapak dan belanja (Elissa, 2013, p. 5).

4. Consumer to Business (C2B). Merupakan model bisnis dimana konsumen (individu) menciptakan dan membentuk nilai akan proses bisnis maksudnya adalah sebuah keadaan dimana sekelompok individu menyediakan layanan jasa atau produk bagi perusahaan yang membutuhkan jasa atau produk. Contoh; istockphoto, mybloggertehemes, kitabisa dan google play (Pradana, 2015, pp. 5-6)

Keuntungan menggunakan e-commerce bagi pembeli adalah pembeli dapat melakukan transaksi secara bebas, terutama dalam memilih dan membandingkan barang atau jasa yang akan dibeli dengan demikian, pembeli bisa mendapatkan barang dan harga yang tepat, sedangkan yang menjadi kerugiannya adalah aspek keamanan dan pengetahuan pembeli. Adapun keuntungan bagi penjual adalah penjual dapat melakukan transaksi lebih efisien dan dapat mendekatkan diri pada customer sehingga, upaya untuk meningkatkan customer bisa dilakukan secara lebih mudah, sedangkan pada sisi kerugian penjual harus menguasai tekhnologi e-commerce secara tepat sehingga, kerugian yang dihadapi dalam penggunaan e-commerce dapat diminimalisir (Sugianto, 2013, pp. 3-4).

\section{PEMBAHASAN}

\subsection{Khiyar dalam Transaksi E-commerce}

Praktik khiyar dalam transaksi e-commerce dapat dilihat dari adanya kebijakan terhadap kebolehan konsumen melakukan pengembalian barang, barang yang dikembalikan dapat ditukar dengan barang yang sejenis ataupun meminta kembali uang yang telah dibayarkan. Pengembalian barang dapat dilakukan apabila konsumen telah memenuhi syarat dan ketentuan yang telah ditetapkan oleh pihak e-commerce. Adapun syarat dan ketentuan pengembalian barang dapat dilihat dari beberapa segi yaitu, dari segi barang, masa pengembalian, dan pengembalian dana.

1. Barang

Pihak e-commerce telah menetapkan ketentuan terkait keadaan barang yang dapat dikembalikan. Penulis telah merangkum dari beberapa $e$-commerce terkait keadaan barang yang dapat dikembalikan, lebih jelasnya adalah sebagai berikut: ( Lihat Tabel 3.1)

Tabel 3. 1 Pengembalian Barang

\begin{tabular}{|l|l|l|l|l|l|}
\hline $\begin{array}{l}\text { Alasan } \\
\text { pengembalian }\end{array}$ & Baru & $\begin{array}{l}\text { Masih } \\
\text { disegel }\end{array}$ & $\begin{array}{l}\text { Lengkap } \\
\text { (aksesoris } \\
\text { dll) }\end{array}$ & $\begin{array}{l}\text { Tidak } \\
\text { rusak }\end{array}$ & $\begin{array}{l}\text { Tag dan } \\
\text { label } \\
\text { tertera }\end{array}$ \\
\hline Rusak & $\times$ & $\times$ & $\vee$ & $\times$ & $\vee$ \\
\hline
\end{tabular}


52 | Jamilah \& Firmansyah: Tinjauan Fikih Muamalah Terhadap Penerapan Khiyar Dalam Transaksi E-Commerce

\begin{tabular}{|l|l|l|l|l|l|}
\hline Cacat & $\times$ & $\times$ & $\vee$ & $\vee$ & $\vee$ \\
\hline Tidak sesuai & $\vee$ & $\times$ & $\vee$ & $\vee$ & $\vee$ \\
\hline $\begin{array}{c}\text { Berubah } \\
\text { pikiran }\end{array}$ & $\vee$ & $\vee$ & $\vee$ & $\vee$ & $\vee$ \\
\hline
\end{tabular}

Sumber: Diolah penulis

\section{Masa Pengembalian}

Masa pengembalian barang dalam transaksi e-commerce berbeda-beda tergantung kebijakan pihak e-commerce, ada yang menerapkan tujuh, empat belas, lima belas, bahkan tiga puluh hari masa kerja. Pengembalian produk dihitung dari mulai produk diterima oleh pembeli sampai tanggal cap pengiriman yang tertera pada produk dikirim kembali kepada pihak $e$ commerce. Contoh pengembalian menggunakan masa tiga puluh hari kerja, jika pembeli menerima produk tanggal 6 Agustus 2017 maka pembeli mempunyai waktu untuk mengirim produk yang dikembalikan sampai 6 September 2017. Pengembalian barang tidak berlaku apabila melebihi batas waktu yang ditentukan oleh pihak e-commerce.

3. Pengembalian Dana

Pembeli yang melakukan pengembalian barang, dapat mengganti dengan barang yang sejenis atau meminta kembali uangnya. Untuk pengembalian produk cacat pihak e-commerce mengembalikan uang via bank atau memberikan voucher senilai dengan jumlah harga pengembalian barang akan tetapi, untuk pengembalian produk tidak cacat atau pengembalian atas inisiatif sendiri, pihak e-commerce hanya menawarkan store credit, pembeli dapat menggunakan untuk membeli barang apapun dengan harga berapapun, maksudnya pembeli yang bertanggung jawab atas kekurangan harga tersebut akan tetapi, jika lebih rendah penjual tidak mengembalikan kelebihan uangnya kepada pembeli.

\subsection{ANALISIS FIKIH MUAMALAH TERHADAP PENERAPAN KHIYAR DALAM TRANSAKSI E-COMMERCE}

Pada dasarnya transaksi e-commerce tidak jauh berbeda dengan jual beli tradisional akan tetapi, jika dicermati ada perbedaan didalamnya yaitu bertemunya kedua pelaku akad dan ketersediaan barang yang akan dijual, adanya perbedaan inilah yang menyebabkan timbulnya khiyar yang berbedabeda dalam transaski e-commerce. Adapun khiyar yang dapat diterapkan dalam transaski e-commerce hanya ada tiga yaitu; khiyar syarat, khiyar aib, dan khiyar ru'yah.

\subsubsection{Khiyar Syarat}

Penerapan khiyar syarat dalam transaksi e-commerce dapat dilihat dari adanya kesepakatan kedua belah pihak terhadap bolehnya syarat dalam transaksi, syarat pada barang yang dapat dikembalikan serta kesepakatan terhadap masa khiyar. 
Jurnal Ekonomi dan Perbankan Syariah

Vol. 6. No.1, April 2018: 49-62, ISSN (cet): 2355-1755 | ISSN (online): 2579-

6437

53

a. Kesepakatan kedua belah pihak

Kesepakatan kedua belah pihak artinya penjual ataupun pembeli menyetujui adanya syarat pengembalian ketika terjadi ketidakcocokan pada barang. Syarat dapat terjadi dari kedua belah pihak misalnya, penjual mensyaratkan barang yang dikembalikan tidak rusak dan tetap baru, dan dari pembeli misalnya, pembeli akan melanjutkan transaksi apabila penjual memberikan hak untuk memilih, pada transaksi $e$-commerce penjual telah memberikan hak memilih kepada pembeli melalui bolehnya pembeli melihat barang di akun penjual, jika pembeli tidak ingin melanjutkan transaksi maka pembeli dapat meninggalkan akun penjual tanpa kompensasi apapun dari penjual.

Tersedianya layanan pengembalian barang menunjukkan bahwa, dalam transaksi e-commerce ada kesepakatan kedua belah pihak, jika tidak ada kesepakatan antara kedua belah pihak, maka tidak ada khiyar. AsySyad'iyah mengatakan bahwa, khiyar dalam jual beli tidak sah kecuali dengan dua perkara yaitu, pertama, adanya kesepakatan antara penjual dan pembeli dengan cara yang khusus dan diketahui keduanya. Kedua, adanya cacat pada barang dagangan yang memperkenankan untuk dikembalikan (Zuhri, 1994, p. 351).

b. Barang yang dikembalikan.

Syarat-syarat keadaan barang yang dikembalikan telah ditetapkan oleh pihak e-commerce, misalnya barang tidak rusak dan tetap baru, jika pengembalian barang karena berubah fikiran. Adanya syarat-syarat pada barang berarti pihak e-commerce telah menerapkan khiyar syarat dalam transaksinya.

c. Masa khiyar syarat.

Pihak-pihak e-commerce telah menetapkan masa pengembalian barang, jika barangnya cepat rusak atau kadaluarsa, maka masa pengembaliannya lebih cepat akan tetapi, jika barangnya tidak cepat rusak maka masa pengembaliannya lebih lama. Masing-masing pihak e-commerce berbedabeda dalam menetapkan masa pengembalian, ada yang menetapkan tujuh, empat belas bahkan tiga puluh hari masa kerja. Pembeli dapat mengetahui lama masa pengembalian barang melalui penjelasan di akun penjual.

Ulama berbeda pendapat terkait masa khiyar syarat, perbedaan mereka dapat dikelompokkan kepada tiga bagian yaitu, Hanafiyah dan Syafi'iyah berpendapat bahwa, masa khiyar tidak boleh lebih dari tiga hari. Sebagaimana Rosulullah SAW bersabda:

Artinya: "Apabila seseorang membeli suatu barang maka kuatkanlah (pada penjual) jangan ada tipuan dan saya berhak memilih dalam tiga hari” (HR. Bukhari dan Muslim dari Ibnu 'Umar). 
Madzhab Hanabilah berpendapat bahwa, waktu tenggang bagi khiyar syarat tidak harus merujuk kepada hadis tersebut melainkan kepada kesepakatan pihak-pihak yang melakukan transaksi, walaupun pada akhirnya melebihi tiga hari, sedangkan madzhab Malikiyah berpendapat bahwa, tenggang waktu khiyar syarat tergantung kepada objek yang diperjualbelikan, jika barang yang dibeli mudah rusak seperti buahanbuahan, masanya hanya satu hari, jika pakaian dan barang-barang tahan lama bisa mencapai tiga hari akan tetapi, jika barang itu seperti tanah dan rumah yang memerlukan waktu lebih lama maka tenggang waktunya dibolehkan lebih dari tiga hari (Elbadriati, 2014, p. 4).

Dari beberapa pendapat di atas dapat disimpulkan bahwa, masa khiyar syarat yang diterapkan di e-commerce diperbolehkan walaupun lebih dari tiga hari, kebolehan tersebut sesuai dengan pendapat madzhab Hanabilah dan Malikiyah yang mengatakan bahwa, masa khiyar syarat tergantung kebutuhan dan kesepakatan pelaku transaksi, tidak mesti tiga hari.

Khiyar syarat berlaku jika penjual dan pembeli sepakat terhadap adanya syarat dalam transaksinya, apabila salah satu atau keduanya tidak sepakat maka tidak ada khiyar didalamnya atau khiyarnya gugur. Penyebab gugurnya khiyar syarat adalah sebagai berikut (Az-Zuhaili, 2011, pp. 196198):

a. Pengguguran yang jelas, yaitu apabila orang yang memiliki khiyar berkata dengan jelas terhadap penggugurannya seperti ia berkata, "saya gugurkan khiyar ini", atau "saya membatalkannya", atau "saya rela dengan jual beli ini”. Dengan mengucapkan kata-kata tersebut maka hak khiyar menjadi batal.

b. Pengguguran dengan isyarat, yaitu jika terdapat tindakan dari orang yang memiliki khiyar yang menunjukkan pada persetujuan jual beli dan penetapan kepemilikan, seperti pembeli yang menawarkan barang yang dibelinya kepada orang lain untuk dijual kembali, maka khiyarnya gugur karena penawaran yang dilakukan pembeli untuk dijual kembali berarti dia memilih untuk memiliki barang dan kepemilikan ini terjadi dengan menggugurkan khiyar.

c. Gugurnya khiyar karena darurat, seperti berakhirnya masa khiyar, meninggalnya orang yang memiliki hak khiyar, sesuatu yang disamakan dengan kematian, rusaknya barang pada masa khiyar, dan tuduhan cacat barang.

Gugurnya khiyar syarat dalam transaksi e-commerce sama halnya dengan gugurnya khiyar syarat pada jual beli tradisional, perbedaannya terletak pada menyatakan secara langsung dan tidak langsung, jika jual beli tradisional gugurnya khiyar dinyatakan secara langsung, sedangkan dalam transaksi e-commerce melalui elektronik dengan cara menuliskan kata yang menunjukkan gugurnya khiyar.

\subsubsection{Khiyar Aib}

Jual beli baik tradisional maupun online perjanjian dilaksanakan atas dasar suka sama suka diantara kedua belah pihak, hal itu hanya dapat terlaksana jika barang dan penukarannya tidak mengandung cacat, karena jika 


\section{| 55}

terdapat cacat pada barang maka akan menyebabkan hilangnya keridhaan salah satu pihak, sehingga pihak yang merasa dirugikan dapat membatalkan perjanjian tersebut (Mujiyatun, 2016, pp. 9-10). Menurut ulama fikih khiyar aib adalah keadaan yang membolehkan pelaku transaksi untuk membatalkan atau meneruskan ketika terdapat cacat pada alat yang dijadikan tukar menukar. Khiyar aib terjadi jika ada cacat pada barang (ma'qud alaih) atau harga (tsaman) karena nilainya yang kurang atau tidak sesuai dengan perjanjian diawal (Syafi'e, 2001, p. 115). Penerapan Khiyar aib dalam transaksi $e$ commerce dapat dilihat dari segi barang yang ingin dikembalikan yaitu, pengembalian barang karena cacat dan rusak, lebih jelasnya adalah sebagai berikut;

\section{a. Cacat pada barang}

Pembeli yang menemukan cacat pada barang yang dibelinya, maka mempunyai hak untuk mengembalikan barang, barang yang dikembalikan tidak harus baru dan masih disegel akan tetapi, kelengkapan aksesoris diperlukan, barang tidak rusak serta adanya tag dan label. Barang yang cacat dapat dikembalikan dalam transaksi e-commerce apabila, cacat bukan disebabkan oleh pembeli melainkan cacat yang sudah ada sejak awal pembelian, baik penjual maupun pembeli tidak mengetahui adanya cacat pada barang dagangan, jika cacat disebabkan oleh pembeli maka menjadi tanggung jawab pembeli dan tidak ada khiyar di dalamnya. Sebagaimana madzhab Malikiyah mengatakan apabila barang yang rusak ditangan penjual maka itu menjadi tanggung jawabnya akan tetapi, jika barang rusak ditangan pembeli maka kedudukannya sama seperti gadai dan pinjaman, atau pembeli yang menanggung kerusakan tersebut (Rusyd, 2002, p. 39).

\section{b. Barang yang rusak}

Barang yang rusak dapat dikembalikan dengan syarat aksesoris serta tag dan label tatap ada, barang tidak harus baru, tidak rusak serta masih disegel. Syarat barang yang rusak dapat dikembalikan sama halnya dengan syarat barang cacat yaitu kerusakan bukan disebabkan oleh pembeli. Sayyid Sabiq mengatakan dalam bukunya apabila barang rusak terjadi setelah serah terima atau ditangan pembeli, maka menjadi tanggung jawab pembeli dan pembeli wajib membayar harga barang apabila tidak ada cara lain dari penjual, atau mengganti barang yang serupa (Sabiq, 2006, p. 156).

Cacat-cacat yang menyebabkan munculnya hak khiyar menurut ulama Hanafiyah dan Hanabilah adalah seluruh unsur yang merusak objek jual beli dan mengurangi nilainya menurut tradisi para pedagang, sedangkan menurut ulama Malikiyah dan Syafi'iyah seluruh cacat yang menyebabkan nilai barang berkurang atau hilang unsur yang diinginkan dari padanya. Salah satu syarat ditetapkannya khiyar aib adalah sebagai berikut (Ridawati, 2016, p. 7); 
a. Pembeli tidak mengetahui adanya cacat pada barang ketika akad berlangsung. Salah satu alasan pembeli ragu untuk melakukan transaksi online, karena ketidaktahuan pembeli terhadap barang yang dibelinya walaupun penjual meyediakan gambar sebagai penjelasan, hal itu tidak sepenuhnya menjelaskan tentang keadaan barang. Pembeli dapat mengetahui ada atau tidak adanya cacat pada barang ketika barang telah sampai kepada pembeli, hal ini menunjukkan bahwa, dalam transaksi $e$ commerce pembeli tidak mengetahui adanya cacat pada barang saat akad berlangsung oleh karena itu, pembeli memiliki hak khiyar.

b. Cacatnya tidak hilang sampai dilakukan pembatalan akad. Sebelum pembeli mengembalikan barang, pihak e-commerce mensyaratkan agar pembeli konfirmasi terlebih dahulu terkait kerusakan atau cacat pada barang, ketika pembeli telah mengembalikan barang yang cacat akan dilakukan proses pengecekan kembali oleh pihak e-commerce, bukti cacatnya harus jelas adanya jika tidak, maka pengembalian dana maupun penggantian barang yang sejenis tidak akan diproses lebih lanjut oleh pihak e-commerce, hal ini menunjukkan bahwa cacat pada barang tersebut tidak hilang sampai pembatalan akad.

c. Tidak disyaratkan bebas dari cacat pada jual beli, jika disyaratkan maka tidak ada khiyar bagi pembeli, maksudnya ketika akad berlangsung penjual tidak mensyaratkan bahwa apabila ada cacat tidak boleh dikembalikan, seperti penjual mengatakan "Barang yang sudah dibeli tidak dapat dikembalikan" kata tersebut dapat berupa perkataan secara langsung maupun melalui tulisan, jika penjual melakukan hal tersebut maka pembeli tidak dapat mengembalikan barang yang dibelinya walaupun ada cacat pada barang. Penerapan khiyar aib dalam transaksi e-commerce dapat dilihat dari ada atau tidak adanya layanan pengembalian barang cacat atau rusak, juga dapat berupa penjelasan diakun penjual tentang tidak bolehnya pengembalian barang yang telah dibeli maka secara otomatis khiyarnya gugur dan pembeli tidak dapat mengembalikan barangnya.

Gugurnya khiyar aib dalam transaksi e-commerce apabila tidak ada konfirmasi pembeli untuk mengembalikan barang yang terdapat cacat, hal tersebut menunjukkan bahwa pembeli rela terhadap jual belinya, kerelaan pembeli terkadang dilakukan secara jelas maupun secara isyarat, jika pembeli rela maka tidak ada khiyar, jika tidak rela maka pembeli memiliki hak khiyar.

Imam Taqiyuddin mengatakan bahwa dalam khiyar aib pembeli memiliki dua pilihan, jika pembeli rela dan puas terhadap barang yang dibeli walaupun terdapat cacat maka khiyar tidak berlaku baginya dan ia harus menerima barang, namun jika pembeli menolak dan mengembalikan barang kepada pemiliknya, maka akad tersebut menjadi batal atau dengan kata lain tidak ada transaksi (Taqiyuddin, 2007, p. 562).

\subsubsection{Khiyar Ru'yah}

Khiyar ru'yah adalah hak yang diberikan kepada pembeli untuk melanjutkan atau membatalkan transaksi ketika pembeli melihat objek akad, 
Jurnal Ekonomi dan Perbankan Syariah

Vol. 6. No.1, April 2018: 49-62, ISSN (cet): 2355-1755 | ISSN (online): 2579-

6437

157

dengan syarat pembeli tidak melihat barang ketika akad (Munif A. G., 2016, p. 6).

Menurut Sayyid Sabiq syarat-syarat ditetapkannya khiyar ru'yah adalah tidak melihat barang ketika terjadi transaksi atau sebelumnya pernah melihat barang akan tetapi ada perubahan atas barang, jika kondisi objek sesuai dengan yang dilihat sebelumnya maka tidak ada khiyar (Sabiq, 2006, p. 158). Sedangkan ulama Hanafiyah mengatakan khiyar ini berlaku ketika pembeli telah melihat barang, karena jika tidak melihat barang dapat mencegah kesempurnaan transaksi, di samping tidak dapat melihat terhadap sifat barang juga dapat mempengaruhi kerelaan pembeli. Hal ini dilakukan untuk mencegah penyesalan terhadap pembeli atas barang yang dibelinya, baik barang sesuai dengan sifat yang disebutkan maupun tidak (Az-Zuhaili, 2011, p. 228).

Salah satu pihak penyedia layanan e-commerce ada yang menerima pengembalian barang karena alasan berubah fikiran serta alasan karena tidak sesuai, ketidaksesuaian barang dapat diketahui pembeli setelah melihatnya. Pada dasarnya pembeli yang melakukan transaksi secara online tidak dapat melihat barang secara langsung, hanya dapat melihat barang melalui gambar di akun penjual, hal ini dapat dianggap bahwa pembeli tidak melihat barang saat akad karena arti melihat itu sendiri adalah melihat barang yang dapat menggambarkan keadaan barang, baik dari segi kuantitas maupun kualitas, sedangkan jika hanya melihat gambar maka pembeli tidak dapat mengetahui spesifikasi barang dengan jelas walaupun spesifikasi barang telah dijelaskan di akun penjual.

Sebagaimana Wahbah Az-Zuhaili mengatakan maksud dari melihat barang adalah melihat sebagian maupun semua barang. Prinsipnya adalah cukup dengan melihat sesuatu yang menunjukkan pada tujuannya dan memberikan pengetahuan tentangnya, jika yang dilihat dapat memberi tahu kondisi barang yang tidak dilihat maka tidak ada khiyar sama sekali akan tetapi, jika barang yang dilihat tidak dapat memberitahu kondisi barang yang tidak terlihat, maka baginya khiyar pada barang yang tidak terlihat, karena tujuannya belum tercapai dengan melihat sebagian barang yang dilihat, maka sekan-akan dia belum melihat sesuatu sama sekali.

Selain tidak melihat barang waktu akad, syarat khiyar ru'yah adalah barang yang akan di transaksikan berupa barang yang secara fisik ada dan dapat dilihat seperti harta tetap dan harta bergerak. Objek transaksi di ecommerce merupakan barang yang dapat dilihat bentuknya walaupun melalui gambar. Sebelumnya juga telah dibahas, barang yang dikembalikan bukan barang habis pakai, hal ini menunjukkan bahwa barang dalam transaksi $e$ commerce merupakan barang yang dapat dilihat bentuknya, untuk mengetahui ketersediaan barang pembeli dapat melihat keterangan di akun penjual, selain gambar barang, penjual juga memberikan keterangan terkait ada atau tidak adanya barang. 
Khiyar ru'yah gugur dengan dua hal yaitu, perbuatan sengaja atau keadaan darurat. Perbuatan sengaja ada dua yaitu kerelaan yang jelas dan kerelaan tidak langsung. Kerelaan yang jelas seperti jika pembeli berkata "saya menyetujui jual beli ini", sedangkan kerelaan secara tidak langsung adalah adanya penggunaan barang setelah ru'yah bukan sebelumnya yang menunjukkan persetujuan dan kerelaan. Adapun perbuatan darurat yang membatalkan khiyar ru'yah adalah semua hal yang membatalkan jual beli secara darurat bukan karena perbuatan pembeli, seperti meninggalnya pembeli, demikian juga rusaknya seluruh barang atau sebagian. Kasani berkata "Asalnya yang membatalkan khiyar syarat dan khiyar aib juga membatalkan khiyar ru'yah, hanya saja khiyar syarat dan khiyar aib batal dengan pembatalan yang jelas, sedangkan khiyar ru'yah tidak batal dengan pembatalan yang jelas baik sebelum maupun sesudah, karena khiyar tersebut ditetapkan oleh syara' sebagai hak Allah, maka khiyar ru'yah tidak batal dengan pembatalan pelaku akad dengan sengaja (Az-Zuhaili, 2011, p. 236).

\section{Kesimpulan}

Khiyar dalam jual beli hukumnya boleh, baik dalam jual beli tradisional maupun e-commerce akan tetapi, dalam transaksi e-commerce hanya ada beberapa khiyar yang dapat diterapkan yaitu; khiyar syarat, khiyar aib dan khiyar ru'yah.

Khiyar syarat dalam transaksi e-commerce dapat dilihat dari tersedianya layanan pengembalian dan syarat barang yang dapat dikembalikan serta penentuan masa pegembalian, hal ini dapat menunjukkan bahwa penjual dan pembeli telah melakukan kesepakatan terhadap adanya syarat dalam jual beli dan syarat barang yang ingin dikembalikan serta masa khiyar, karena ketiga hal tersebut merupakan syarat ditetapkannya khiyar syarat dalam jual beli, sedangkan khiyar aib dapat dilihat dari alasan pengembalian barang karena cacat dan rusak, penyebab kerusakan barang, serta tidak adanya syarat bebas cacat dari penjual waktu akad, sedangkan khiyar ru'yah dapat dilihat dari ada atau tidak adanya pengembalian setelah pembeli melihat barang yang tidak dilihat waktu akad. Menurut penulis khiyar yang telah diterapkan dalam transaksi $e$-commerce sesuai dengan yang disyariatkan.

\section{DAFTAR PUSTAKA}

Aedy, H. (2011). Teori dan Aplikasi Etika Bisnis Islam. Bandung: Alfabeta.

Amiruddin, M. M. (2016). Hak memilih dalam transaksi online: studi komparasi antara Zalara, Lazada, Blibli. Jurnal Ekonomi Syari'ah, Vol 1, No.1 Februari.

Amiruddin, M. M. (2016). Hak Memilih dalam Transaksi Online: Studi Komparasi antara Zalara, Lazada, Blibli. Jurnal Ekonomi Syari'ah, Vol 1, No.1 Februari.

Ardianto, R. A. (2014). Perlindungan hukum terhadap konsumen dalam transaksi onine. Jurnal serambi hukum Vol 8, No. 2 Agustus. 
Jurnal Ekonomi dan Perbankan Syariah

Vol. 6. No.1, April 2018: 49-62, ISSN (cet): 2355-1755 | ISSN (online): 25796437

\section{9}

As-Shawi. (2004). Fiqh ekonomi keuangan Islam. Jakarta: Darul Haq.

Az-Zuhaili, W. (2011). Fiqh Islam wa Adillatuhu. Jakarta: Gema Insan.

Elbadriati, B. (2014). Rasionalitas Penerapan Khiyar dalam Jual Beli Islam. Jurnal Ekonomi Islam, Vol 5, No 1 Juni.

El-Islamy, H. (2002). E-Business an islamic Prespektive. Kuala Lumpur: A.S Noordeen.

Elissa, M. d. (2013). Analisi faktor-faktor yang mempengaruhi keputusan pembelian via internet pada toko online. Jurnal Teknik Industri, Vol 8, No 3, September.

Harun, S. A. (2016). Prinsip Khiyar (Pilihan) dalam Undang-Undang Berkaitan Jualan Barang Menurut Islam. Al-Qanatir International Journal Of Islamic Studies, Vol 4, No 1.

Hendrawati, Y. K. (2015). Jual beli online dalam prespektif hukum Islam. Jurnal Informasi dan pengembangan Iptek, Vol 11, No.1.

Iwanuddin. (2014). Bisnis Maya dalam Prespektif hukum Islam. Jurnal Istinbath, Vol 11, No 2 September .

Mardani. (2013). Fiqh Ekonomi Syari'ah. Jakarta: Kencana.

Markom, H. H. (2016). Prinsip Khiyar (Pilihan) dalam Undang-undang berkaitan jualan barang menurut Islam. Al-Qanatir Iternational Journal of Islamic Studies, Vol 4, No 1.

Martadiredja, J. S. (2008). Teori E-commere: Kunci sukses perdagangan di internet. Yogyakarta: Gava Media.

Muchtar, K. (1995). Ushul Fiqh. Jakarta: Dana Bhakti.

Mujiyatun, R. (2016). Konsep Khiyar A'ib dan Relevansinya dengan Garansi. Jurnal Hukum Ekonomi Syari'ah dan Ahwal Syahsiyah, Vol 1, No 1.

Munif, A. g. (2016). Problematika perdagangan online telaah terhadap aspek khiyar dalam e-commerce. jurnal Al-manahij, Vol 9, No 2 Desember

Munif, A. G. (2016). Problematika Perdagangan Online Telaah Terhadap Aspek Khiyar dalam E-commerce. Jurnal Al-Manahij, Vol 9, No 2 Desember.

Pradana, M. (2015). Klasifikasi jenis-jenis bisnis E-commerce di Indonesia. Jurnal Neu-bis, Vol 9, NO.2, Desember.

Qardhawi, Y. (1997). Peran Nilai dan Moral dalam Perekonomian Islam. Jakarta: Rabbani Pers.

Ridawati, M. (2016). Konsep Khiyar Aib dan Relevansinya dengan Garansi. Jurnal Hukum ekonomi Syari'ah dan Ahwal Syahsiyah, Vol 1, No 1.

Rusyd, F. A. (2002). Bidayatul Mujtahid wa Nihayatul Muqtashid. Jakarta: Pustaka Amani.

Sabiq, S. (2006). Fiqih Sunnah. Jakarta Selatan: Pena Pundi Aksara.

Sugianto, H. (2013). Kajian Efektifitas Sistem Informasi Penjualan Online: Studi Kasus www.Tokprada.com. Jurnal Paradigma, Vol 15, No 1, Maret. 
60 | Jamilah \& Firmansyah: Tinjauan Fikih Muamalah Terhadap Penerapan Khiyar Dalam Transaksi E-Commerce

Suzanto, I. s. (2015). pengaruh kepuasan transaksi online shopping dan kepercayaan konsumen terhadap sikap serta perilaku konsumen pada E-commerce. Jurnal komputech dan Bisnis, Vol 9, No 1, Juni.

Syafi'e, R. (2001). Fiqih Muamalah. Bandung: Pustaka Setia.

Taqiyuddin, I. (2007). Kifayatul Akhyar. Surabaya: Bina Iman.

Zuhri, M. (1994). Terjemahan Fikih Empat Madzhab. Semarang: As-Syafi'i. 